\title{
The Opportunities and Pitfalls of Pakistan's Trade with China and Other Neighbors
}

\section{Naved Hamid ${ }^{*}$ and Sarah Hayat ${ }^{* *}$}

\begin{abstract}
While Pakistani trade with India could give a boost to Pakistan's economy, there are other neighbors with whom trade could be equally important. We look at this aspect of regional trade and show that promoting trade with the rest of Pakistan's neighbors could have a significant positive impact on the country's growth. We show that Pakistan's trade with these neighbors has grown rapidly over the last 10 years and at present they constitute the largest market for Pakistani exports. We also explain how these exports are not only important in terms of absolute value, they have also contributed to the development of new export products. The overall impact on Pakistan's economy could well be to raise the trend growth rate for the next decade or so by 2 to 3 percentage points above the historical trend growth rate of 5 percent per annum.
\end{abstract}

Keywords: Exports, regional trade, Pakistan, China, UAE, Central Asia, Afghanistan

\section{JEL classification: F13.}

\section{Introduction}

There is increasing recognition in Pakistan that regional trade could be an important driver of growth for the country. However, much of this debate has focused on India-Pakistan trade. ${ }^{1}$ While, undoubtedly, trade with India could give a tremendous boost to Pakistan's economy, there are other neighbors with whom trade could be equally important. We propose to look at this neglected aspect of regional trade and show that promoting trade with the rest of Pakistan's neighbors could have a significant positive impact on the country's growth over the next decade or more. Trade with

\footnotetext{
* Director of the Centre for Research in Economics and Business at the Lahore School of Economics, Pakistan.

** Research Assistant, Centre for Research in Economics and Business at the Lahore School of Economics, Pakistan.

${ }^{1}$ An important exception was a report prepared at the request of Jahangir Khan Tareen, federal minister for industries, production, and special initiatives, for the Government of Pakistan in 2005 by a team of economists led by Ijaz Nabi (see Nabi et al., 2005).
} 
India and trade with the other neighbors are two sides of the same coinpromoting trade with both would have tremendous synergies. The overall impact on Pakistan's economy could well be to raise the trend growth rate for the next decade or so by 2 to 3 percentage points above the historical trend growth rate of 5 percent per annum.

Section 2 provides a review of the trends in growth in trade, particularly exports in the last decade. In the next three sections, we discuss trends in exports at the aggregate and commodity level, as well as the pitfalls, opportunities, and appropriate policies to promote exports with respect to Pakistan's three largest trading partners of its neighboring countries, i.e., China, the United Arab Emirates (UAE), and Afghanistan. Section 6 briefly reviews the potential for trade with Central Asia, overland through Afghanistan. Section 7 concludes the study.

\section{Regional Trade}

There is an impression that Pakistan trades (excluding imported crude oil and petroleum products) primarily with the US and Europe. This was the case for a long time, but it has changed in the last decade. In 2010, about 25 percent of Pakistan's exports and 35 percent of imports were from neighboring countries (UAE, China, Afghanistan, India, and Iran); as a group, these neighbors are now are more important for Pakistan's trade than North America or Europe (Table 1). The fact that trade between Pakistan and its neighbors has increased so rapidly, despite the lack of progress in formal regional economic agreements such as the South Asian Association for Regional Cooperation (SAARC), the SAARC Preferential Trade Agreement (SAPTA), South Asia Free Trade Area (SAFTA), and Economic Cooperation Organization (ECO), is indicative of the potential and dynamics of trading with neighboring countries.

Table 1: Pakistan's trade in 2010

\begin{tabular}{lcccc}
\hline & \multicolumn{2}{c}{ Exports } & \multicolumn{2}{c}{ Imports } \\
\cline { 2 - 5 } Country & USD billion & \% Share & USD billion & \% Share \\
\hline Neighbors* & 5.4 & 25.2 & 13.1 & 34.9 \\
North America & 3.9 & 18.2 & 2.1 & 5.6 \\
Europe & 5.0 & 23.5 & 4.8 & 12.8 \\
East Asia (excl. China) & 1.2 & 5.4 & 6.3 & 16.8 \\
Pakistan's total & 21.4 & & 37.5 & \\
\hline
\end{tabular}

* China, UAE, Afghanistan, India, and Iran.

Source: United Nations Statistics Division, UN comtrade. 
We focus primarily on exports. This is not to imply that imports are not important, but simply that, historically, poor export performance has been Pakistan's Achilles' heel and the main reason for the country's stopgo growth experience since the 1970s. Therefore, it is critical for Pakistan to improve its export performance, and to do that it must diversify its exports both in terms of products and markets. We show that this had already started happening in the last decade (2000-10) due to growing trade with its neighbors. We also argue that these neighbors could provide the dynamic and potentially large export markets that might help resolve Pakistan's historic export dilemma and serve as one of the drivers of its growth for the next decade or more.

In the last decade, although aggregate exports to neighboring countries fluctuated greatly, they grew at an average of more than 19 percent per annum compared to only 6 percent to the rest of the world (Figure 1). As a result, its neighbors' share in Pakistan's total exports increased from less than one tenth to about one fourth in 2010, when three of the world's five top export markets for Pakistan were neighboring countries.

\section{Figure 1: Trends in Pakistan's exports to its neighbors and ROW*}

\section{Growth Rates of Pakistan's Exports}

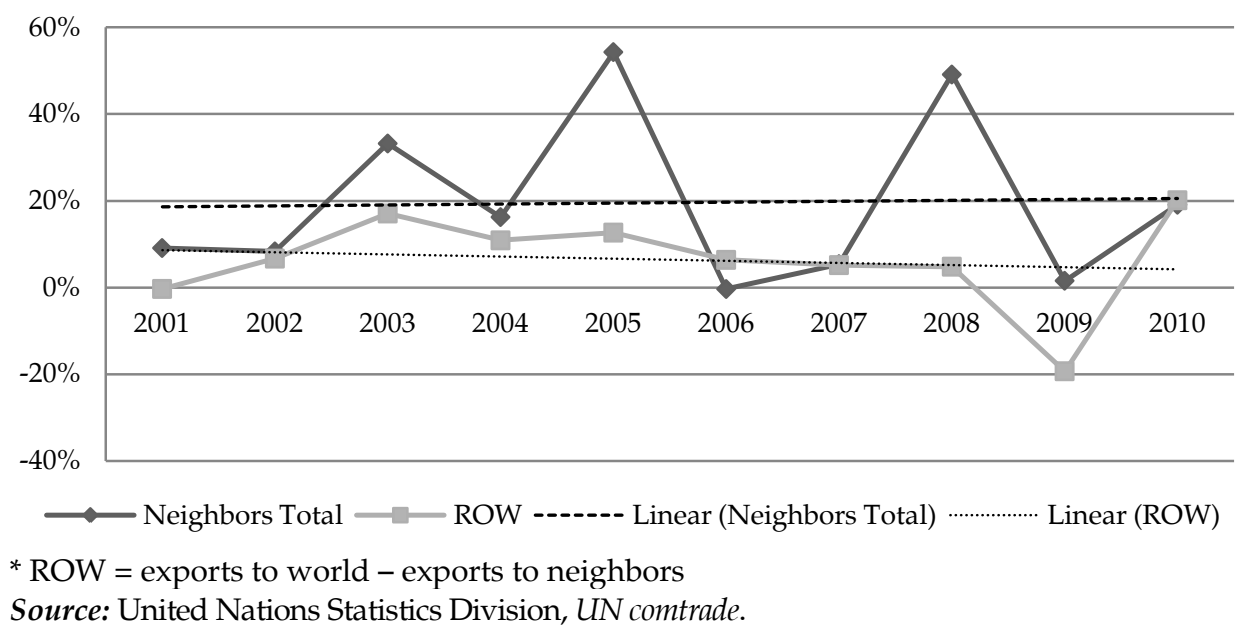

In the last decade, exports to all neighboring countries grew more rapidly than to the rest of the world, but exports to Afghanistan grew fastest (Table 2). As a result, Afghanistan's share of Pakistan's exports increased sixfold, making it the third most important export market in the world for Pakistan in 2010. The next most rapid growth in exports was to Iran, but this 
was from a very small base and, consequently, total exports to Iran were still relatively small in 2010. The export shares of the UAE and China both increased by about 2.5 times during this period and, by 2010, they were the second and fourth most important export markets in the world, respectively, for Pakistan. Although exports to India increased more slowly than to the other neighbors, they grew faster than exports to the rest of the world and, as a result, India's export share almost doubled during this period.

Table 2: Neighbors' export shares, 2000-10

\begin{tabular}{lccrc}
\hline & \multicolumn{2}{c}{2000} & \multicolumn{2}{c}{$\mathbf{2 0 1 0}$} \\
\cline { 2 - 5 } Country & USD million & \% Share* & $\begin{array}{c}\text { USD } \\
\text { million }\end{array}$ & \% Share* \\
\hline UAE** & 304.5 & 3.3 & $1,782.9$ & 8.3 \\
Afghanistan & 124.0 & 1.3 & $1,684.7$ & 7.9 \\
China & 244.6 & 2.7 & $1,435.9$ & 6.7 \\
India & 65.0 & 0.7 & 275.0 & 1.3 \\
Iran & 16.6 & 0.2 & 182.2 & 0.9 \\
Neighbors' total share & 754.8 & 8.2 & $5,360.7$ & 25.2 \\
Pakistan's total exports & $9,201.1$ & & $21,413.1$ & \\
\hline
\end{tabular}

* As a percentage of Pakistan's total exports.

** Data for UAE is based on import values reported by UAE.

Source: United Nations Statistics Division, UN Comtrade.

In brief, regional trade expanded rapidly during the last decade with imports and exports from Pakistan's neighbors increasing, on average, by 17 and 19 percent per annum, respectively. However, while the growth in exports to all the neighboring countries was high-ranging from 29 percent per annum for Afghanistan to 15 percent per annum for Indiathe products exported and the factors responsible for this growth were quite different for each country. Therefore, it is necessary to look in more detail at each individual country's experience to get an idea of the nature of expansion in regional trade, as well as the potential opportunities and pitfalls. The next three sections examine in greater detail the trends in export growth in the last decade for China, the UAE, and Afghanistan, both at the aggregate and commodity levels.

\section{People's Republic of China}

China has been the world's fastest-growing major economy for many years; it is now the world's second largest economy, after the US, the 
largest exporter, and the second largest importer of goods. Its overall trade was close to USD 3 trillion in 2010, with exports and imports of USD 1.6 trillion and 1.4 trillion, respectively (International Monetary Fund, 2011). China's outward foreign direct investment (FDI) has also shown a marked increase in recent years, and was USD 68 billion in 2010 (United Nations Conference on Trade and Development, 2011).

Overland trade ties between Pakistan and China were established in 1979, following the completion of the all-weather Karakoram Highway. However, a very small proportion of Pakistan's trade with China is through this route, and the overland link is seen primarily as enhancing the country's defense. In fact, Pakistan has always looked at China largely from a security perspective-as a counter to political pressure from the US, support in a confrontation with India, and as a source of military hardware. China, as an emerging global economic power, offers immense opportunities to Pakistan, particularly as a neighbor and an old ally.

Pakistan's economic interdependence with China has grown rapidly in the last decade-in 2010, the latter was Pakistan's second largest source of imports and its fourth largest market for exports. Pakistan's exports to China grew rapidly throughout the decade, with growth accelerating sharply following the signing of a free trade agreement (FTA) in 2006. The average annual export growth increased from 19 percent between 2003 and 2006 to 26 percent from 2007 to 2010. As a result, China's share in Pakistan's exports almost doubled in just three years (Table 3).

Table 3: Pakistan's exports to China (USD million)

\begin{tabular}{|c|c|c|c|c|c|c|c|c|c|c|}
\hline & \multicolumn{2}{|c|}{2000} & \multicolumn{2}{|c|}{2003} & \multicolumn{2}{|c|}{2005} & \multicolumn{2}{|c|}{2007} & \multicolumn{2}{|c|}{2010} \\
\hline & & $\%$ & & $\%$ & & $\%$ & & $\%$ & & $\%$ \\
\hline & Value & Share & Value & Share & Value & Share & Value & Share & Value & Share \\
\hline Exports & 244.6 & 2.7 & 259.6 & 2.2 & 435.7 & 2.7 & 613.8 & 3.4 & 1435.9 & 6.7 \\
\hline
\end{tabular}

Source: United Nations Statistics Division, UN Comtrade.

Even though aggregate exports to China have increased rapidly, one needs to look at the structure of exports to fully understand the dynamics of this change. A review of the structure of exports reveals two things. First, the export structure in 2010 is not encouraging, with raw materials and primary manufactures such as cotton fiber, chromium ores, and cotton yarn accounting for almost two thirds of total exports (Table 4). Second, this structure has not changed much in the last decade-the same six commodities account for over 80 percent of exports in 2000 and 2010. 
However, over the ten years, the shares of chromium ores and cotton yarn have increased at the expense of cotton fabrics, a change that most would see as a move backward.

Table 4: Structure of Pakistan's exports to China, 2000-2010

\begin{tabular}{|c|c|c|c|c|c|}
\hline \multirow[b]{2}{*}{ No. } & \multirow[b]{2}{*}{ Commodity } & \multicolumn{2}{|c|}{2000} & \multicolumn{2}{|c|}{2010} \\
\hline & & USD million & $\begin{array}{c}\% \\
\text { Share* }\end{array}$ & USD million & $\%$ Share $^{*}$ \\
\hline 1 & Cotton yarn, excl. thread & 100.0 & 40.9 & 737.3 & 51.3 \\
\hline 2 & $\begin{array}{l}\text { Chromium ores and } \\
\text { concentrates }\end{array}$ & 4.5 & 1.8 & 137.6 & 9.6 \\
\hline 3 & Cotton fabrics, woven & 56.5 & 23.1 & 99.6 & 6.9 \\
\hline 4 & Textile fibers: cotton & 10.7 & 4.4 & 75.9 & 5.3 \\
\hline 5 & Fish, crustaceans, mollusks & 15.3 & 6.3 & 67.5 & 4.7 \\
\hline 6 & Leather & 15.9 & 6.5 & 46.0 & 3.2 \\
\hline 7 & $\begin{array}{l}\text { Machinery and transport } \\
\text { equip. }\end{array}$ & 0.8 & 0.3 & 45.4 & 3.2 \\
\hline \multirow[t]{3}{*}{8} & Plastics in primary form & 2.5 & 1.0 & 38.2 & 2.7 \\
\hline & Subtotal & 206.2 & 84.3 & $1,247.5$ & 86.9 \\
\hline & Total exports to China & 244.6 & & $1,435.9$ & \\
\hline
\end{tabular}

* As a percentage of Pakistan's total exports to China.

Source: United Nations Statistics Division, UN Comtrade.

Pakistan needs to shift from exporting primary commodities and simple manufactures to higher-value-added products, if export growth is to be sustained and exports are to contribute to expanding employment and GDP in the country. The FTA with China should give Pakistan an edge over other countries in a number of potentially high-growth products as it provides market access at zero duty for cotton fabrics, bed-linen and other home textiles, leather articles, sports goods, and fruits and vegetables among other goods (Pakistan, Ministry of Textile Industry, 2008). However, in almost all these products, Pakistani exporters have failed to make headway because of nontariff barriers. For example, Pakistan is a major exporter of towels and bed-linen to the US and Europe, but exports of these products to China are negligible. ${ }^{2}$ Pakistan needs to focus on

\footnotetext{
${ }^{2}$ According to a former chairperson of the Towel Manufactures' Association of Pakistan, "The landed cost of Pakistani towels in China is 15 to 20 percent less than the price of equivalent towels made in China and with zero duty under the FTA we should be able to export substantial quantities to China. But no large store or distributor in China will buy imported towels unless the Chinese Government gives them the go-ahead. Since, thus far, the Chinese Government has not given its okay; Pakistan is unable to export any towels to China" (personal interview with Tahir Jahangir, 22 July 2012).
} 
having these nontariff barriers removed in areas that are its export strengths, such as cotton fabrics, bed-linen, towels, and sports goods.

Besides exports, investment from China could provide a major boost to Pakistan's export industry. According to Eichengreen, Rhee, and Tong (2007), the structure of China's exports has been changing over the years-from "clothing, footwear, other light manufactures and fuels that dominated its trade in the 1980s and early 1990s, toward office machinery, telecommunications, furniture, and industrial supplies in the late 1990s and automated data processing equipment and consumer electronics in recent years" (p. 202). In other words, China has been moving up the value chain, but because of its huge labor force, it has continued to export laborintensive products as well. However, after almost 30 years of rapid growth, most of the surplus labor has now been absorbed and wages are rising rapidly, particularly in the coastal belt. As a result, exporters in China are losing competitiveness in the more labor-intensive industries and beginning to look at the possibility of relocating these industries elsewhere.

In Asia, this has happened many times before, i.e., as wages rose in one country, its export industry tended to move to manufacturing more sophisticated products at home and relocated the labor-intensive product processes to neighboring countries. This started with industry relocating from Japan to Korea, Taiwan, Singapore, and Hong Kong in the 1960s and 1970s, then to Thailand, Malaysia, and Indonesia in the 1980s and to China and Vietnam in the 1990s and 2000s. This process has often been referred to as "the flying geese model of Asian economic development," with Japan in the forefront (Kojima, 2000; Kumagai, 2008).

Owing to China's huge labor force, it has taken much longer for this process to start, but it is beginning to happen, with industries being relocated to Vietnam, Laos, and Cambodia. According to the World Investment Report 2011, "A new round of industrial restructuring and upgrading is taking place in China, and some low-end, export-oriented manufacturing activities have been shifting from coastal China to low income countries in South-East Asia and also Africa" (United Nations Conference on Trade and Development, 2011, p. 50). However, the Southeast Asian countries do not have enough population to absorb a significant portion of the labor-intensive industry relocating from China once the process starts in earnest. South Asia, because of its large population, should be the main recipient of this industry and Pakistan should aim to be the leader in this regard. 
This is a window of opportunity for Pakistan, which has a large textile sector as well as strong clusters in sports goods, surgical instruments, and light engineering. It therefore needs to develop a strategy to attract Chinese investment in these areas. Thus far, Pakistan's approach has been the traditional one, i.e., trying to attract investment from China in import-substituting industry by providing incentives, including special industrial zones, and corporate income tax and import duty concessions for the manufacture of consumer durables, such as televisions, refrigerators, air conditioners, washing machines, etc. This strategy has failed in the past and it is unlikely to do much better this time since it will only attract investment for assembly plants producing for the domestic market.

Pakistan's strategy should aim to attract Chinese investment into export industries, particularly those labor-intensive industries that are likely to be relocating out of China in the next 10 years and that are also Pakistan's strengths, such as garments, textiles, leather and footwear, surgical goods, cutlery, and sports goods. The strategy needs to be developed in partnership with larger exporters and the representatives of export associations in these industries. Once such a strategy is developed, the government should leverage its long-standing relationship with the Chinese government to garner the latter's support in implementing the key elements of the strategy.

In addition, Pakistan should seize the opportunity provided by China's drive to accelerate development in its western provinces. The Karakoram Highway provides the shortest overland route to the sea for these provinces, and China has indicated an interest in upgrading the highway to handle heavy traffic. If Pakistan were to prioritize this project and control the movement of Islamic militants crossing over into China, the resulting transit trade through Pakistan could provide a tremendous boost to economic activity. It would attract Chinese investment into the northern regions of Pakistan and create opportunities for the export of Pakistani products to western China.

Any discussion on Pakistan's economic relations with China would be incomplete without at least a brief look at the import side. Pakistan's imports from China have grown dramatically from about USD 0.55 billion in 2000 to USD 5.25 billion in 2010. China's share in Pakistan's total imports has increased from less than 5 percent to over 14 percent during this period. This is not surprising since China's exports to the rest of the world have also grown rapidly, but because of Pakistan's security dependence on China, the government tends to turn a blind eye to violations on imports from the latter. This has provided an opportunity for collusion between unscrupulous Pakistani importers and Chinese exporters to misclassify 
imports from China and understate their value to evade import duties and taxes. As a result, the actual increase in imports has been even greater than that indicated by official figures.

Although there is no way to estimate the full extent of tax evasion, one can get a rough idea of the undervaluation by comparing the value of "imports from China" reported by Pakistan and "exports to Pakistan" reported by China in the UN Comtrade dataset. Exports reported by China exceeded imports reported by Pakistan by 32 percent in 2010 (Table 5). The underreporting is probably even greater since exports are reported on a free-on-board (f.o.b.) basis and imports on a cost-insurance-and-freight (c.i.f.) basis, and the cost of "insurance and freight" is generally between 10 and 20 percent of the import value (see World Bank, n.d.). Even with a conservative 10 percent adjustment for insurance and freight, the underreporting comes to 45 percent. Thus, actual imports from China in 2010 were in the range of USD 7 billion to 8 billion.

The problem is not only the loss in government revenue, but also the impact of this "unfair" competition on domestic industry. The rapid growth in imports from China has decimated a number of industries in Pakistan; generally, these have been industries that were dominated by small to medium firms producing for the local market. This was not because the imported products were of better quality-based on anecdotal evidence and personal experience, they are in many cases of very poor quality and often imitations of established local brands-but because they were extremely cheap due to the evasion of taxes and import duties. Small local producers were unable to compete with these products because the effective tariff (including sales tax) on the final product imported from China is, in many cases, substantially lower than the effective tariff on the raw materials used by small manufacturers in Pakistan. Small producers have to buy raw materials from commercial importers, who have to pay the statutory rates of duties and a 16 percent sales tax on the duty-paid value of imports because they are not eligible for the concessions that large manufacturers enjoy under Pakistan's notorious Statutory Regulatory Order regime (Pursell, Khan, \& Gulzar, 2011).

Table 5: Pakistan-China trade: Value understatement (USD million)

\begin{tabular}{lccccc}
\hline Reporting country & $\mathbf{2 0 0 0}$ & $\mathbf{2 0 0 3}$ & $\mathbf{2 0 0 5}$ & $\mathbf{2 0 0 7}$ & $\mathbf{2 0 1 0}$ \\
\hline Imports reported by Pakistan & 550.1 & 957.3 & $2,349.4$ & $4,164.2$ & $5,247.7$ \\
Exports reported by China & 670.3 & 1855 & $3,427.7$ & $5,831.4$ & $6,937.8$ \\
\hline
\end{tabular}

Source: United Nations Statistics Division, UN Comtrade. 
However, the impact of Chinese imports has not been all negative. There has been a huge consumer gain in industries where Pakistan did not have any local manufacturing, such as mobile phones. Pakistan would have never achieved the tele-density that it has, if only "full" duty-paid and sales tax-paid phones were available in the market. In the motorcycle industry, which was highly protected and had an oligopolistic structure, Chinese imports have led to huge producer and consumer gains. The opening up of the motorcycle industry by removing entry restrictions on the assembly of motorcycles and allowing the import of parts and components from China in 2006 resulted in a dramatic growth spurt in the industry. The domestic production of motorcycles rose from less than 600,000 in 2004/05 to over 1.6 million in 2010/11 (Association of Pakistan Motorcycle Assemblers, 2010). One of the reasons for the large increase in size of the domestic market for motorcycles was probably the decline in their price in real terms (by about 40 percent) between 2006 and $2012 .^{3}$

Thus, a sensibly designed and implemented trade policy-for example, one that eliminates the distinction between commercial and industrial importers of raw materials and components-would not only mitigate the negative impact of imports on the local industry, but also dramatically improve its prospects. Clearly, the automobile industry in Pakistan is a prime candidate for "motorcycle industry type" opening up to imports from China and India.

\section{United Arab Emirates}

The UAE is Pakistan's closest neighbor by sea (after Oman)-the distance from Karachi to Dubai is almost the same as from Karachi to Islamabad. Estimated to have 8.5 percent of the world's oil reserves and the fifth largest gas reserves, the UAE's economy and exports are obviously dominated by the oil and gas sector. However, around one third of its total merchandise exports are re-exports (World Trade Organization [WTO], 2012), which means that it is also an important trading hub and packaging and distribution center. In 2010, the UAE's total nonoil exports (including re-exports) were USD 126.4 billion, of which India had the highest share (33.7 percent), while Pakistan, with a 2.5 percent share, ranked among the top ten. As for the UAE's imports, the top two countries for nonoil commodity imports are India and China with 17.1 and 10.3 percent,

\footnotetext{
3 The price of a Honda $70 \mathrm{cc}$ motorcycle, the most popular make and size in Pakistan, increased from PKR 54,000 in 2006 ("Motorcycles sales stagnating," 2007, April 4) to PKR 67,000 in 2012 (Qeemat Prices in Pakistan, 2011), i.e., by less than 25 percent, while the overall price level more than doubled (the consumer price index increased from 132 in 2005/06 to 269 in 2011/12).
} 
respectively (WTO, 2012), while Pakistan's share is about 1 percent (United Nations Statistics Division, n.d.).

The UAE is an important economic partner for Pakistan, and there are many dimensions to the relationship. For example, there are over half a million Pakistanis resident in the UAE, who officially remitted USD 2.6 billion to Pakistan in 2010/11. Most large international banks have regional offices in the UAE with many Pakistani professionals on their staff, including in senior management positions. Most Pakistanis traveling overseas pass through the UAE - there are more than 100 flights a week from Pakistan to the UAE, more than to any other country in the world or between any two destinations in Pakistan. During the civil disturbances in Karachi in the 1990s, many Pakistani business families set up operations in UAE and it became a major destination for Pakistani investors, particularly for real estate. Dubai is an offshore base for many Pakistani businesses that maintain a presence there to meet with foreign buyers, suppliers, investors, and bankers, who for reasons of security or inconvenience are reluctant to travel to Pakistan. Until recently, a substantial part of the India-Pakistan trade was routed through the UAE to circumvent the trade restrictions imposed by the two countries. Finally, the UAE is Pakistan's second largest export market, with a share of 8.3 percent of total exports in 2010.

Having so many linkages also has its pitfalls, since it makes the UAE a convenient base for avoiding or exploiting the Pakistan government's economic regulations. The UAE is the most commonly used channel for capital flight or for taking advantage of arbitrage possibilities created by government policies. For example, when Pakistan has provided product-specific export incentives in the past-such as tax rebates, duty drawbacks, and subsidized credit-Pakistani businesses have mislabeled or overvalued exports to the UAE in order to make windfall gains at the state's expense. This is evident from the large gap between "exports to UAE" as reported by Pakistan and "imports from Pakistan" as reported by the UAE in the UN Comtrade dataset. Between 2003 and 2007, for instance, the former were two to three times the value of the latter (United Nations Statistics Division, n.d.).

It is also the likely explanation for the large year-to-year fluctuations in the value of exports of individual products (in the Pakistan data), since the duty drawbacks on individual items were regularly adjusted (often in response to stories in the press of the misuse of these incentives by exporters). For example, in 2003, "fabrics from man-made fibers" and "household linen" accounted for 12.8 and 16.2 percent, respectively, of Pakistan's total exports to the UAE (as reported by 
Pakistan), but these fell to only 2.9 and 6.7 percent in 2005, in which year clothing exports accounted for 16.3 percent of the total. Clothing exports came down to 6.4 percent in 2007.4 As the government phased out various export incentives after 2007 because of fiscal difficulties, the gap between the numbers reported by Pakistan and the UAE also started to decline and had virtually disappeared by 2009.5

This creates a problem in analyzing trends in exports to the UAE. To circumvent this, at least at the aggregate level, we use the value of "imports from Pakistan" for Pakistan's exports to the UAE as reported by the UAE instead of "exports to UAE" as reported by Pakistan. We see that exports so measured increased by almost six times between 2000 and 2010, and growth accelerated after 2005 (Table 6). ${ }^{6}$ Thus, in the last decade, exports to the UAE grew at an annual average rate of 18 percent, which resulted in the its share of Pakistan's exports increasing from 3.3 percent in 2000 to 8.3 percent in 2010.

Table 6: Pakistan's export trend to UAE (USD million)

\begin{tabular}{lcccccc}
\hline Reporting country & $\mathbf{2 0 0 0}$ & $\mathbf{2 0 0 3}$ & $\mathbf{2 0 0 5}$ & $\mathbf{2 0 0 7}$ & $\mathbf{2 0 0 9}$ & $\mathbf{2 0 1 0}$ \\
\hline $\begin{array}{l}\text { Exports reported by } \\
\begin{array}{l}\text { Pakistan* } \\
\text { Imports reported by UAE* }\end{array}\end{array}$ & 516.9 & $1,010.2$ & $1,012.9$ & $1,503.6$ & $1,340.6$ & $1,497.4$ \\
\hline
\end{tabular}

* Excluding petroleum exports.

Source: United Nations Statistics Division, UN Comtrade.

This rapid export growth has taken place without any focused effort by the government. However, if Pakistan were to implement a strategy of leveraging the existing advantages-proximity, outstanding connectivity, its extensive banking presence in the UAE, a large Pakistani diaspora as well as those from other South Asian countries with similar cultures and taste, and excellent political relations-to promote exports, it could significantly increase exports further, not only to the UAE but to the entire region. The UAE is potentially a huge market for Pakistani consumer products, such as packaged foods, clothing, furniture, and furnishings, and for entertainment content such as music and television serials. It could also become a showcase for Pakistani products for export to the rest of the world.

${ }^{4}$ Calculated by the authors using data from the UN Comtrade dataset (United Nations Statistics Division, n.d.).

${ }^{5}$ Keeping in mind the point made earlier that exports are reported on an f.o.b. basis and imports on a c.i.f. basis, it seems that exports are still being overstated by about 10-20 percent.

${ }^{6}$ Interestingly, "exports to UAE" as reported by Pakistan, show an opposite trend, i.e., phenomenal growth between 2005 and 2007 and then a collapse. 
Some of this may already be happening, but a focused approach by the government to promote the UAE as Pakistan's offshore hub could make a qualitative difference. This may involve establishing a trade and investment liaison office in Dubai, which has high-level representation of all the relevant government ministries and agencies-including the Ministry of Finance, Board of Investment, and Trade Development Authority of Pakistan-and setting up a Pakistan expo-center. The latter should be run as a public-private partnership between the government and major exporters/export associations. It should have, in addition to exhibition halls, common facilities such as office space and business services for exporters' use to reduce their cost of interacting with international buyers (earlier suggested in Ahmad, Mahmud, Hamid, \& Rahim, 2010, pp. 43-44). In brief, the strategy's goal should be to make it possible for the UAE to play a role similar for Pakistan as Hong Kong did for China in the 1990s. ${ }^{7}$

\section{Afghanistan}

Historically, Afghanistan has been a major trading partner of Pakistan, though in the past most of this trade was undocumented. Following the Soviet invasion of Afghanistan in 1979, and the subsequent period of civil war, formal trade between Pakistan and Afghanistan ceased but informal trade between the two countries probably remained substantial. However, since the end of the Taliban regime in 2001 and resumption of normal trade relations, documented trade between the two countries has expanded rapidly. Between 2002 and 2010, there was a sevenfold increase in Pakistan's exports to Afghanistan, and by 2010 Afghanistan was Pakistan's third largest export market, accounting for 7.9 percent of the latter's total exports.

Afghanistan is not only an important export market for Pakistan, it has also been instrumental in the development of a number of nontraditional exports that have long-term export potential. For example, Afghanistan accounted for 28 to 55 percent of Pakistan's total exports of vegetables and fruit, petroleum products, cement, and metal manufactures in 2010 (Table 7). These are the documented exports-since informal trade between the two countries was also substantial, Pakistan's exports of nontraditional products to Afghanistan were probably larger and even more diverse. The development of such exports to Afghanistan is important. It is always difficult for a country to develop new export products, but once the export

${ }^{7}$ This point was first made by Ashwani Saith in his comments on this paper at the Lahore School's Conference on Management of the Pakistan Economy (May 2012). 
capacity, production experience, and domestic supply chains are developed for a particular product, it becomes much easier to export that product to other markets. Therefore, the export of these products to Afghanistan is likely to promote their future export to other countries.

Table 7: Structure of Pakistan's exports to Afghanistan, 2010

\begin{tabular}{|c|c|c|c|}
\hline No. & Commodity & $\begin{array}{c}\text { Value } \\
\text { (USD million) }\end{array}$ & $\%$ Share \\
\hline 1 & Rice & 95.8 & 4.2 \\
\hline 2 & Vegetables and fruit & 144.5 & 35.7 \\
\hline 3 & Petroleum and petroleum products & 658.9 & 55.0 \\
\hline 4 & Lime, cement, and construction materials & 186.4 & 39.5 \\
\hline 5 & Metal manufactures & 57.0 & 27.6 \\
\hline \multirow[t]{3}{*}{6} & Machinery and transport equipment & 59.6 & 10.5 \\
\hline & Subtotal & $1,202.2$ & \\
\hline & Total exports to Afghanistan & $1,684.7$ & \\
\hline
\end{tabular}

* As a percentage of Pakistan's total exports of the commodity to the world.

Source: United Nations Statistics Division, UN Comtrade.

While it is evident that Afghanistan contributed significantly to Pakistan's export growth in the last decade-accounting for 13 percent of the entire increase in exports during this period-it could potentially have an even greater impact in the next decade or so. No doubt, there is some uncertainty about future political developments in Afghanistan, but Pakistan is in a position to create a win-win outcome for both countries. However, this will require Pakistan to switch from looking at Afghanistan through the security lens to an economic one. If Pakistan's decision makers are able to change this mindset, it would greatly improve the prospects of peace. It would also make it possible to invest in appropriate infrastructure, such as roads and truck-ports at the border, which could have a substantial additional impact on trade with Afghanistan.

An increase in Afghanistan-Pakistan trade will promote prosperity in the border regions and beyond, which should help break the cycle of militancy and violence in the region. This, in turn, would make it easier for Pakistani banks and businesses to establish a physical presence in Afghanistan and expand exports of Pakistani products, such as food, textiles and clothing, tractors and transport equipment (motorcycles, rickshaws, etc.), electrical machinery (fans, washing machines, electric motors, etc.), and simple industrial and agricultural machinery (lathes, 
diesel motors and pumps, grain threshers, etc.). Pakistan should focus on establishing its economic presence in Afghanistan rather than worrying about other countries capturing its markets. Cultural and ethnic linkages are continually demonstrated to be far more powerful drivers of trade than political affiliations; it is therefore likely that products and businesses from Pakistan, particularly from Khyber Pakhtunkhwa, would have an edge over those from most other countries.

As Nabi (2012) elaborates, the areas that now constitute Pakistan were historically important transit hubs for trade routes between Central Asia and Persia on one side and China and India on the other. Peshawar was a great trading city at the time, and it has the potential of once again emerging as a key transit hub for trade in the region. Afghanistan, neighbored by Iran to the west and by Turkmenistan, Uzbekistan, and Tajikistan to the north, is Pakistan's bridge to Central Asia. It is a member of SAARC and ECO and, given its increasing emphasis on regional trade, is undertaking what is termed the "New Silk Road" trade project-a major element of which is the development of infrastructure in the country to facilitate overland trade. The Afghanistan-Tajikistan Bridge, which was completed in 2007, is an important component of the road network for trade between Afghanistan and Central Asia. Similarly, the Afghanistan-Pakistan Transit Trade Agreement, signed in 2010, aims to promote not only the smooth flow of goods between the two countries, but also to provide access to the sea for Afghanistan and ultimately for the rest of Central Asia. Therefore, peace in Afghanistan would not only boost Pakistan's trade with Afghanistan, it would also facilitate exports to Central Asia and the import of gas and power from the latter, which could go a long way toward easing Pakistan's critical energy constraint.

\section{Central Asian Republics}

The Central Asian republics (CARs), i.e., Kazakhstan, Kyrgyzstan, Tajikistan, Turkmenistan, and Uzbekistan, with a combined population of 61 million and GDP of USD 219 billion, are becoming an increasingly important economic region (Table 8). After a prolonged period of low (or negative) growth, the region has grown at an impressive rate in the last decade. Some of their main advantages have been their abundant natural resources (oil, gas, gold, etc.) and a "reasonable infrastructure and human capital as legacies of Soviet rule" (Dowling \& Wignaraja, 2006, p. 10). 
Table 8: Central Asia 2010

\begin{tabular}{|c|c|c|c|c|c|}
\hline \multirow{3}{*}{ Country } & \multirow[t]{2}{*}{ Population $^{\text {a }}$} & \multirow[t]{2}{*}{ GDP b } & \multirow[t]{2}{*}{ Imports ${ }^{b}$} & \multicolumn{2}{|c|}{$\begin{array}{c}\text { Average growth rate } \\
2000-10\end{array}$} \\
\hline & & & & GDP $c$ & Imports $\mathrm{c}$ \\
\hline & Million & USD billion & USD billion & $\%$ & $\%$ \\
\hline Kazakhstan & 16 & 149 & 33 & 9 & 19 \\
\hline Kyrgyzstan & 5 & 5 & 6 & 4 & 26 \\
\hline Tajikistan & 7 & 6 & 3 & 8 & 21 \\
\hline Turkmenistan & 5 & 20 & 5 & 14 & 16 \\
\hline Uzbekistan & 28 & 39 & 9 & 7 & 15 \\
\hline Total & 61 & 219 & 56 & & \\
\hline
\end{tabular}

Sources: $\mathrm{a}=$ World Bank (2012), World dataBank; b = United Nations Statistics Division, UN Comtrade; $\mathrm{c}=$ authors' calculations using $\mathrm{a}$ and $\mathrm{b}$.

Trade has grown rapidly with the development of the market economy and increasing incomes. In 2010, the CARs' imports were USD 56 billion, having expanded at an average rate of almost 19 percent per annum during 2000-10. Individually, all the countries exhibited an increased demand for imports, with import growth ranging from 15 to 26 percent per annum; in Kazakhstan, the largest of the CAR economies, imports increased by more than six-fold in ten years. The importance of imports from their neighboring countries has also increased in the last decade, the share going up from 47 to 62 percent. In 2000, Russia accounted for the largest share of imports, but imports from China have grown dramatically, and in 2010 it was the most important source, accounting for more than USD 16.5 billion in imports (Table 9). The value of imports from Turkey rose seven-fold during this period, and imports from Iran also increased rapidly. However, imports from Pakistan declined-in 2010, they were less than half that in 2000. The key factor in the decline was the disruption of Pakistan's overland trade with Central Asia because of the war in Afghanistan. 
Table 9: The CARs' imports from their neighbors

\begin{tabular}{lcc}
\hline & $\mathbf{2 0 0 0}$ & $\mathbf{2 0 1 0}$ \\
\cline { 2 - 3 } Country & USD million & USD million \\
\hline China & 767.3 & $16,530.6$ \\
Russia & $2,810.6$ & $15,110.0$ \\
Turkey & 342.4 & $2,515.4$ \\
Iran & 249.9 & 760.6 \\
Pakistan & 26.7 & 12.1 \\
Afghanistan & - & 17.1 \\
Subtotal & $4,196.9$ & $34,945.7$ \\
Total imports from the world & $\mathbf{8 , 8 0 0 . 0}$ & $\mathbf{5 6 , 0 0 0 . 0}$ \\
\hline
\end{tabular}

Note: Export values from partners to CARs reported.

Source: United Nations Statistics Division, UN Comtrade.

To assess the potential market for Pakistan, it is useful to look at what the CARs are importing from their neighbors. Imports from Russia were primarily petroleum, iron, steel, and different types of heavy machinery and mechanical apparatus. However, more relevant for Pakistan were the imports from China and Turkey. Table 10 summarizes the CARs' major imports from these two countries, and also presents Pakistan's world exports of these commodity groups. We can see that Pakistan actually exports significant quantities of four of the ten main items that the CARs were importing from China and Turkey in 2010. Two items of particular interest are "clothing and accessories" and "textile yarn, fabric, etc." - the CARs' two largest imports from China and also Pakistan's biggest exports to the rest of the world. Nonmetallic mineral manufactures, i.e., cement, and miscellaneous manufactured goods are also potential export items for Pakistan. 
Table 10: Main exports from China and Turkey to the CARs and Pakistan's exports of these to the world, 2010 (USD million)

\begin{tabular}{|c|c|c|c|c|}
\hline No. & Commodity & China & Turkey & $\begin{array}{l}\text { Pakistan's } \\
\text { exports to } \\
\text { world }\end{array}$ \\
\hline 1 & Clothing and accessories & $4,874.3$ & 115.4 & $3,930.2$ \\
\hline 2 & Textile yarn, fabric, etc. & $2,204.9$ & 187.1 & $7,847.7$ \\
\hline 3 & Footwear & $1,554.2$ & & 92.7 \\
\hline 4 & Nonmetallic mineral manufactures & 631.9 & & 505.7 \\
\hline 5 & Road vehicles & 601.5 & & 56 \\
\hline 6 & Special industrial machinery & 593.6 & 35.0 & 124.8 \\
\hline 7 & Metal manufactures & 553.2 & 301.3 & 206.2 \\
\hline 8 & Misc. manuf. goods & 548.6 & 130.8 & $1,036.1$ \\
\hline 9 & Electric machine apparatus, parts, etc. & & 290.1 & 51.6 \\
\hline \multirow[t]{3}{*}{10} & Plastic, nonprimary form & & 123.9 & 26.5 \\
\hline & Subtotal & $11,562.2$ & $1,183.6$ & $13,877.5$ \\
\hline & Total exports to CARs & $16,530.6$ & $2,515.4$ & $21,413.1$ \\
\hline
\end{tabular}

Note: Blank cells indicate values of less than USD 0.1 million.

Source: United Nations Statistics Division, UN Comtrade.

Given the positive growth trajectory of the CARs and the fact that the distance from Peshawar to Tashkent $(1,281 \mathrm{~km})$ is even smaller than that from Peshawar to Karachi $(1,382 \mathrm{~km})$, Central Asia appears to offer huge economic opportunities for Pakistan, both as a market for the latter's exports and as a low-cost supplier of energy. However, without peace in Afghanistan, which is necessary for the transport of goods overland and for building gas pipelines and power lines between Central Asia and Pakistan, this potential cannot be realized.

\section{Conclusion}

Pakistan's trade with its neighbors has grown rapidly over the last 10 years; together, they constitute the largest market for Pakistani exports. These exports are not only important in terms of absolute value, they have also contributed to the development of new export products such as fruit and vegetables, cement, and metal manufactures to Afghanistan; jewelry to the UAE; and chromium ores to China. Given the growth prospects of most of the neighboring governments, we can expect the potential for Pakistan's exports to continue to expand. It is up to Pakistan to adopt appropriate policies to take advantage of this potential. 
This will require a change in policymakers' perspectives, who need to adopt an "economy first" approach. Such a change, together with a strategy to focus in each country on a few areas that are likely to provide the greatest immediate benefits, could significantly accelerate exports. This may, in turn, be a driver of sustained growth for the next decade or more. Policies with respect to China include gaining market access for Pakistan's exports and attracting Chinese investment to the export industries. The UAE should be developed as an offshore center for facilitating exports and investment inflows. Trade with Afghanistan and Central Asia will require a change in mindset to give priority to economic issues, measures to end the conflict in Afghanistan, and building the necessary infrastructure for overland trade and energy imports. If successfully implemented, these policies are likely to result in a significant upward shift in the trend growth rate for exports, which could add 2 to 3 percent to the GDP growth rate. This would, in turn, ease the balance-of-payments constraint and help end the "stop-go" growth cycle in which Pakistan has been trapped since the 1990s. 


\section{References}

Afghanistan, Dehsabz-Barikab City Development Authority. (2012). Welcome to the Kabul new city official website. Retrieved May 7, 2012, from http:/ / www.dcda.gov.af/

Ahmad, H., Mahmud, M., Hamid, N., \& Rahim, T. (2010). A strategy for reversing Pakistan's dismal export performance (Policy Paper No. 01-10). Lahore, Pakistan: Centre for Research in Economics and Business.

Association of Pakistan Motorcycle Assemblers. (2010). Eleven years motorcycle production of Pakistani assemblers and non-APMA members (3-Japanese). Retrieved June 4, 2012, from http://www.motorcycleexport.com/tenyearsmotorcycleproduction.html

Australia, Department of Foreign Affairs and Trade. (2011). Afghanistan country brief. Retrieved May 7, 2012, from http://www.dfat.gov. $\mathrm{au} / \mathrm{geo} /$ afghanistan/afghanistan_country_brief.html

Dowling, M., \& Wignaraja, G. (2006). Central Asia's economy: Mapping future prospects to 2015 (Silk Road Paper). Baltimore, MD: John Hopkins University, Central Asia-Caucasus Institute.

Eichengreen, B., Rhee, Y., \& Tong, H. (2007). China and the exports of other Asian countries. Review of World Economics, 143(2), 201-226.

Embassy of the United Arab Emirates in Washington, DC. (2012). Business and trade: Trade and export. Retrieved May 7, 2012, from http:/ /www.uae-embassy.org/business-trade/trade-export

International Monetary Fund. (2011). World economic outlook database [Data file]. Retrieved April 2012, from http:/ /www.imf.org/external/pubs/ft/weo/2011/02/weodata/ weorept.aspx?sy $=2000 \&$ ey $=2010 \& s c s m=1 \&$ ssd $=1 \&$ sort $=$ country\&d $\mathrm{s}=. \& \mathrm{br}=1 \& \mathrm{pr} 1 . \mathrm{x}=37 \& \mathrm{pr} 1 . \mathrm{y}=5 \& \mathrm{c}=924 \& \mathrm{~s}=\mathrm{NGDP}$ RPCH\&grp=0\&a$=$

Kojima, K. (2000). The "flying geese" model of Asian economic development: Origin, theoretical extensions and regional policy implications. Journal of Asian Economics, 11(4), 375-401.

Kumagai, S. (2008). A journey through the secret history of the flying geese model (Discussion Paper No. 158). Chiba, Japan: Institute of Developing Economies. 
Motorcycles sales stagnating. (2007, April 4). Daily Times, pp. 5/13. Retrieved August 10, 2012, from http://www.dailytimes.com.pk/ default.asp?page=2007\04\04\story_4-4-2007_pg5_13

Nabi, I., et al. (2005). Towards a prosperous Pakistan: A strategy for rapid industrial growth. Pakistan: Lahore University of Management Sciences.

Nabi, I. (2012). Back to the future: Regional trade as a vent for economic growth. Paper presented at the $8^{\text {th }}$ Annual Conference on Management of the Pakistan Economy, Lahore School of Economics, Pakistan.

Pakistan, Ministry of Commerce. (2010). Afghanistan-Pakistan transit trade agreement 2010. Retrieved May 7, 2012, from http://www.commerce.gov.pk/APTTA/APTTA.pdf

Pakistan, Ministry of Textile Industry. (2008). Pak-China free trade agreement: Analytical report on textiles and clothing. Islamabad, Pakistan: Author. Retrieved April 3, 2012, from www.rdacell.com/Documents/Pakistan-ChinaFree.pdf

People's Republic of China, Ministry of Commerce. (2012). Brief statistics on China's import and export in December 2011. Retrieved April 3, 2012, from http://english.mofcom.gov.cn/aarticle/statistic/ BriefStatistics /201201/20120107927529.html

Pursell, G., Khan, A., \& Gulzar, S. (2011). Pakistan's trade policies: Future directions (Working Paper No. 11/0361). London, UK: International Growth Centre.

Qeemat Prices in Pakistan. (2011). Honda CD70 2012 price in Pakistan. Retrieved August 10, 2012, from http:/ /www.qeemat.com/hondacd70-2012-price-in-pakistan/

United Nations Conference on Trade and Development. (2011). World investment report 2011. Geneva, Switzerland: Author. Retrieved from http:/ / www.unctad-docs.org/UNCTAD-WIR2011-Full-en.pdf

United Nations Statistics Division. (n.d.). UN Comtrade [Data file]. Retrieved March-June 2012, from http:/ / comtrade.un.org/db/default.aspx 
US-China Business Council. (2012). US-China trade statistics and China's world trade statistics. Retrieved April 3, 2012, from http:/ / www.uschina.org/statistics/tradetable.html

World Bank. (2012). World dataBank: World development indicators (WDI) E global development finance (GDF) [Data file]. Retrieved March-June 2012, from http://databank.worldbank.org/ddp/home.do? Step $=2 \&$ id $=4 \&$ hActiveDimensionId=WDI_Series

World Bank. (n.d.). World integrated trade solution [Computer software]. Retrieved June 26, 2012, from http://wits.worldbank.org/WITS/ wits/WITSHELP/Content/Data_Retrieval/T/Intro/B2.Imports_E xports_and_Mirror.htm

World Bank and Development Research Center of the State Council. (2012). China 2030: Building a modern, harmonious and creative high-income economy (Conference ed.). Washington, DC: World Bank.

World Trade Organization. (2012). Trade policy review: United Arab Emirates (WT/TPR/S/262). Geneva, Switzerland: Author. 